\title{
Watershed Influences and In-Lake Processes-A Regional-Scale Approach to Monitoring a Water-Supply Reservoir, Lake Houston near Houston, Texas
}

Created in 1954 by an impoundment on the San Jacinto River, Lake Houston currently (2008) supplies about 20 percent of the total source water for the city of Houston. Houston historically has relied on ground water as the major source of supply. As a result of regulations to limit ground-water withdrawals because of associated land subsidence (effective in 2010), the lake will become the primary source of water supply for the city in the future (Harris-Galveston Coastal Subsidence District, 1999).

Since 1983 the U.S. Geological Survey (USGS), in cooperation with the City of Houston, has collected water-quality and lake-level data at Lake Houston, as well as discharge and intermittent water-quality data at its major inflowing tributaries. Previous studies indicate that Lake Houston is shallow, eutrophic, light limited and has a variable hydrologic regime with water residence times ranging from 12 hours to 400 days (Lee and Rast, 1997; Liscum and East, 2000). Spring Creek, a tributary that drains the western, more urban, part of the Lake Houston watershed, contributes more sediment and nutrients than East Fork San Jacinto River, a tributary that drains the more rural, eastern part of the watershed (Sneck-Fahrer and others, 2005). This fact sheet explains the importance of monitoring for management of the resource and describes ongoing research in the Lake Houston watershed by the USGS and the City.

\section{The Importance of Monitoring for Source-Water Protection and Water-Supply Operations}

With increased demand for Lake Houston water, a comprehensive understanding of the factors that affect water quality in the lake is needed. Because of the proximity of the lake to Houston, the effects of urbanization on the water quality of the lake and its tributaries are of particular concern. Urbanization might cause changes in stream hydrology that decrease water residence times in the lake and increase sediment and nutrient loads to the lake. Increased nutrient loads to Lake Houston can cause an increase in plant growth and decay (eutrophication), which decreases dissolved oxygen concentrations and thereby degrades water quality and biological communities.

Real-time water-quality monitoring of the tributaries and the lake allow observation of the timing of large inflows and resulting effects on in-lake processes that might affect source-water quality. Tracking inflows through the lake can give water-treatment facility operators time to respond to changes in source-water quality. Of particular concern in Lake Houston are inflows that might adversely affect taste and odor of the water.

\section{Ongoing Research in the Lake Houston Watershed}

Because of the need for a scientifically based source-water protection plan for Lake Houston, the USGS, in cooperation with the City of Houston, has established monitoring stations in the Lake Houston watershed to evaluate the effects of watershed influences and in-lake processes on Lake Houston water quality. The watershed has been monitored since 2005 using two continuous water-quality monitoring stations, one in the more rural eastern part of the watershed and the other in the more urban western part. Since 2006, Lake Houston has been monitored at three sites (for example, fig. 1) in the southern part of the lake.

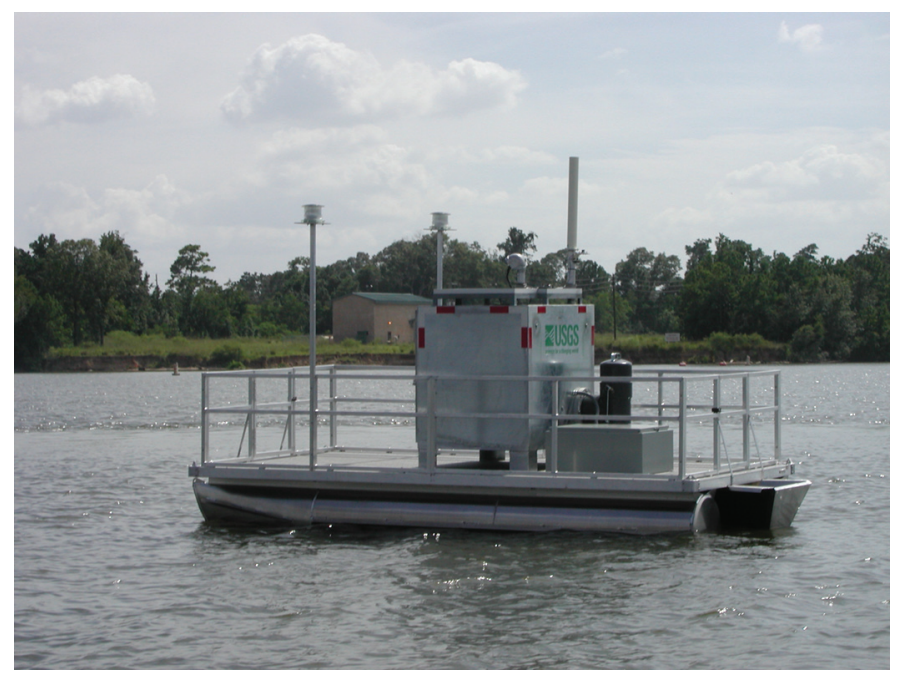

Figure 1. USGS lake water-quality monitoring station 295554095093401, Lake Houston near Mouth of Jack's Ditch.

\section{Monitoring the Contributing Watershed}

Real-time continuous monitoring of the watershed (fig. 2) provides hourly data on physical water-quality properties such as dissolved oxygen, $\mathrm{pH}$, and temperature. The real-time water-quality monitors on the tributaries give an early warning of water-quality changes that might be about to occur in the lake. For example, during an October 2006 inflow, elevated turbidity in the tributaries was observed about 24 hours before turbidity increased at a site in the lake (fig. 3). During periods of increased flow into Lake Houston, actinomycetes bacteria in storm runoff might cause taste-and-odor problems. The realtime tributary data inform water treatment facility operators of impending changes in water quality of the lake and give them lead time to adjust water treatment accordingly. 


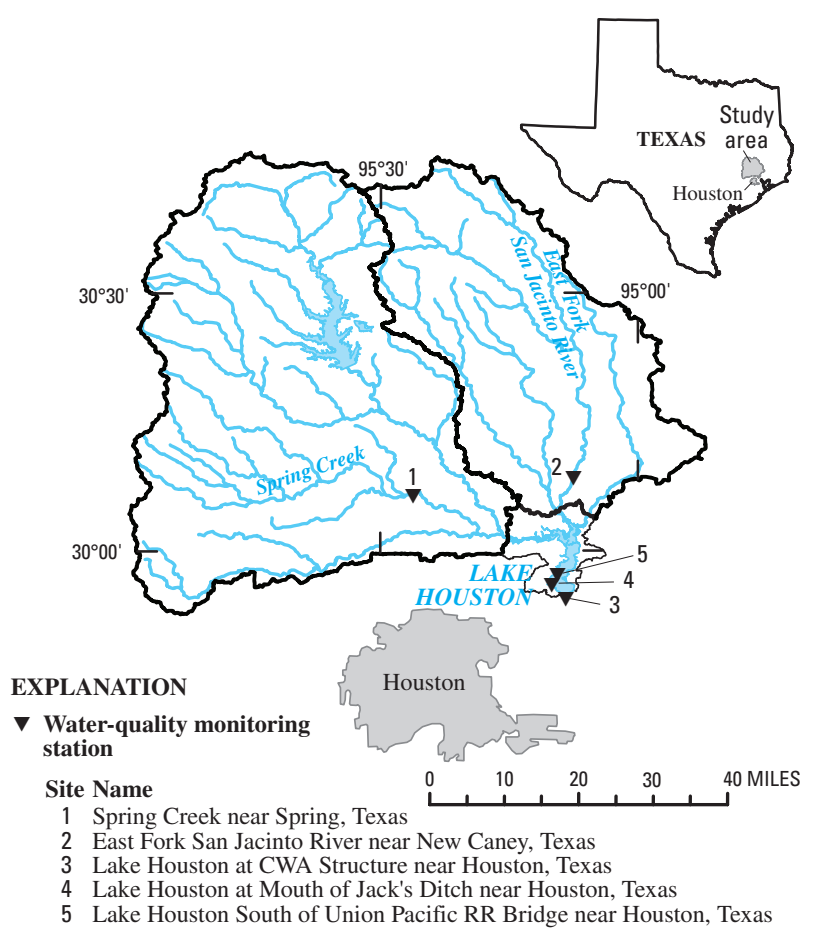

Figure 2. Lake Houston watershed and water-quality monitoring stations near Houston, Texas.

\section{Monitoring Lake Houston}

Three real-time water-quality monitoring stations (fig. 2) with vertical profiling capabilities were installed at three sites in the lake in 2006. These stations provide continuous water-quality data from multiple depths in the lake as well as atmospheric data. Each station consists of a multiparameter instrument that measures temperature, specific conductance, $\mathrm{pH}$, dissolved oxygen, turbidity, chlorophyll, and light. The real-time data collected on the lake provide information that can enhance understanding of the in-lake chemical and biological processes that affect Lake Houston water quality. For example, the data can indicate periods of low dissolved oxygen concentration (fig. 4), which facilitate the release of manganese and nutrients from lake-bottom sediment. High concentrations of manganese might cause taste-and-odor problems (Rasmussen

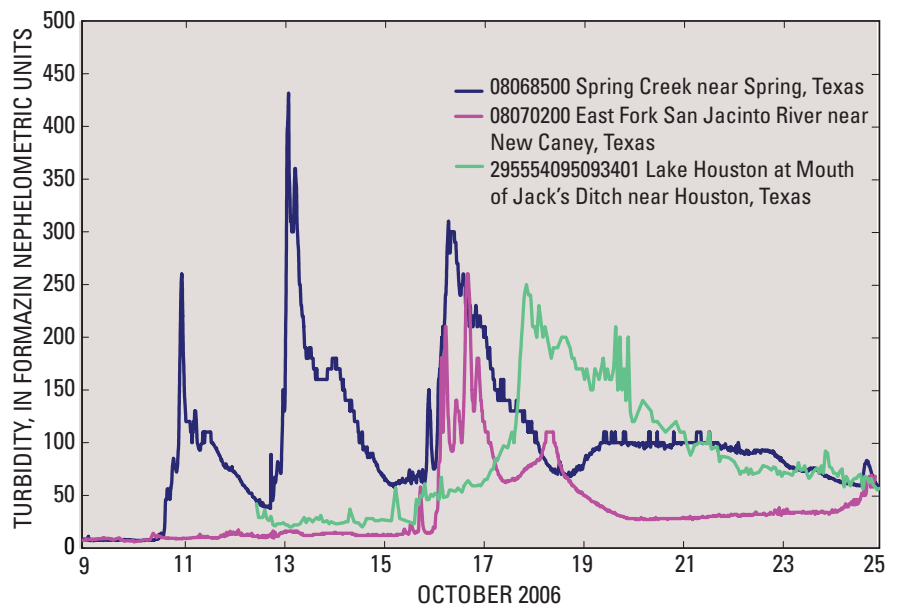

Figure 3. Increase in turbidity measured at the two tributary monitoring stations from October 2006 storm in Lake Houston watershed and response of turbidity at site 295554095093401, Lake Houston near Mouth of Jack's Ditch. and McAllister, 2005), and the release of nutrients, particularly phosphorous, might stimulate the growth of algae that produce compounds that cause undesirable taste and odor (Wetzel, 2001). Discrete, multidepth, water-quality samples also are being collected and analyzed on a biweekly-to-monthly basis to complement and verify the real-time data.

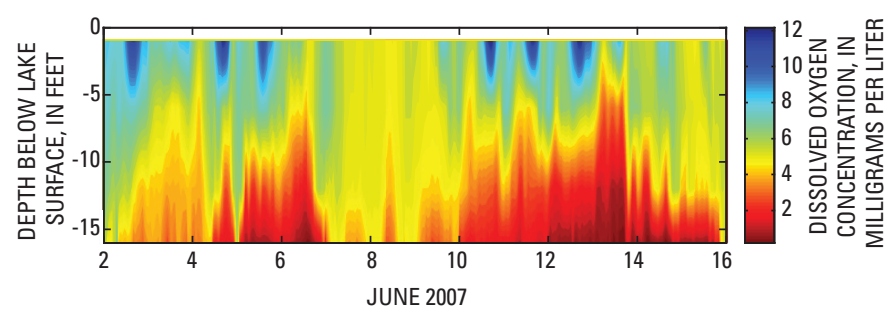

Figure 4. Dissolved oxygen concentrations in water at the USGS real-time water-quality monitoring station 295554095093401, Lake Houston near Mouth of Jack's Ditch, June 2-16, 2007.

A comprehensive understanding of the processes affecting water quality is required to develop effective best-management practices and source-water protection plans. Combined, the watershed and lake monitoring will increase the understanding of the effects of inflows, nutrient and sediment loads, and water-column structure on the chemistry and biology of Lake Houston. Knowledge gained from these studies will help ensure that Lake Houston remains a sustainable source of water supply for Houston.

All continuous real-time data collected as a part of this program are available through the USGS National Water Information System Web Interface (NWISWeb) for Texas at http://waterdata.usgs.gov/tx/nwis/rt/.

\section{References}

Harris-Galveston Coastal Subsidence District, 1999 [amended 2001], District regulatory plan: accessed January 8, 2008, at $h t t p: / / w w w$. hgsubsidence.org/Assets/PDFDocuments/HGRegPlan.pdf

Lee, R.W., and Rast, Walter, 1997, Light attenuation in a shallow, turbid reservoir, Lake Houston, Texas: U.S. Geological Survey Water Resources Investigations Report 97-4064, 33 p.

Liscum, Fred, and East, J.W., 2000, Estimated effects on water quality of Lake Houston from interbasin transfer of water from the Trinity River, Texas: U.S. Geological Survey Water Resources Investigations Report 00-4082, 50 p.

Rasmussen, P.P., and McAllister, D.H., 2005, Monitoring the water quality of Lake Olathe, Johnson County, Kansas: U.S. Geological Survey Fact Sheet 2005-3093, 2 p.

Sneck-Fahrer, D.A., Milburn, M.S., East, J.W., and Oden, J.H. 2005, Water-quality assessment of Lake Houston near Houston, Texas, 2000-2004: U.S. Geological Survey Scientific Investigations Report 2005-5241, 55 p.

Wetzel, R.G., 2001, Limnology (3d ed.): San Diego, Academic Press, $1,006 \mathrm{p}$.

\section{—Timothy D. Oden and Jennifer L. Graham}

\section{For additional information, contact}

Director

USGS Texas Water Science Center

World Wide Web: http://tx.usgs.gov/

E-mail: gs-w-txpublic-info@usgs.gov 